\title{
Immune Effect of Viable and Heat Killed Lactobacillus acidophilus in Mice Infected with Salmonella typhimurium
}

\author{
Zahraa K. Zedan \\ Department of Biotechnology, College of Science, Al-Nahrain University, Baghdad-Iraq. \\ E-mail: zahraa84biotech@yahoo.com.
}

\begin{abstract}
This study was designed to evaluate the immunological effect of viable and heat killed Lactobacillus acidophilus in mice infected with Salmonella typhimurium. The immunological parameters were total and absolute counts of leucocytes and phagocytic index of peritoneal cells. Twelve mice were divided into four groups. Each group consists of 3 mice. Group 1 was used as a negative control. Group 2 was infected with Salmonella typhimurium and use as positive control. Group 3 was fed with viable Lactobacillus acidophilus culture, and infected with culture of Salmonella typhimurium. Group4 was fed with heat killed Lactobacillus acidophilus culture, and infected with Salmonella typhimurium. Results indicated that treatment mice with viable Lactobacillus acidophilus were effective in enhancing the immune responses against Salmonella typhimurium as compared to negative (distilled water) and positive (Salmonella typhimurium) controls. While, mice fed with heat killed Lactobacillus acidophilus showed no enhancing immune effect on mice infected with Salmonella typhimurium.
\end{abstract}

Keywords: Probiotic, Immunological effect, Salmonella typhimurium.

\section{Introduction:}

Probiotic are nonpathogenic microorganisms that, when ingested, exert a positive influence on health or physiology of the host. They can influence intestinal physiology either directly or indirectly through modulation of the endogenous ecosystem or immune system [1].

Probiotics exert their benefits through several mechanisms; they prevent colonization, cellular adhesion and invasion by pathogenic organisms, they have direct antimicrobial activity and they modulate the host immune response [2]. There is increasing evidence indicating health benefits by consumption of foods containing microorganisms (probiotics). A number of clinical trials have been performed to evaluate the effects in the prevention and treatment of gastrointestinal diseases caused by pathogenic microorganisms or by disturbances in the normal microflora [3].

There is a growing interest in probiotics as a safe way of changing the intestinal bacterial flora. Probiotic bacteria such as lactic acid bacteria (LAB) may have potential in several gastroenterological conditions, especially when the intestinal flora has been disturbed [4].
Probiotics also termed as biotherapeutic agent because its therapeutic uses to modulate immunity, lower cholesterol, prevent cancer, improve lactose intolerance and prevent or reduce the effect of a topic dermatitis, diarrhea,constipation, as well as, candidiasis and urinary tract infection [5].

Probiotics have been suggested as an alternative therapy for the treatment of infectious gastroenteritis or in the prevention of antibiotic-induced diarrhoea. These biotherapeutic agents are preparations of nonpathogenic microorganisms known to have beneficial effects on the digestive ecosystem and to confer resistance to infections as demonstrated by studies in animal models as well as by clinical trials [6].

\section{Material and Methods}

\section{A. Bacterial isolates}

Lactobacillus acidophilus and Salmonella typhimuruim were supplied by Immunology $\mathrm{Lab}$ in the department of Biotechnology, College of Science, Al-Nahrain University. Lactbacillus acidophillupreviously isolated from vaginal swab and Salmonella typhimuruim previously isolated from patient's stool infected with Salmonellosis. 


\section{B. Viable and heat killed Lactobacillus culture}

The Lactobacillus was grown in de Mann, Rogosa and Sharp (MRS) broth (Merck) media for $18 \mathrm{hr}$ at a $37^{\circ} \mathrm{c}$. This activated culture was centrifuged at $2000 \mathrm{~g}$ at $4^{\circ} \mathrm{C}$ and resuspended in phosphate-buffered saline with $\mathrm{pH} 7$, in order to obtain $10^{9}$ colony forming units (cfu)/ml which were obtained by using Mc Farland method [7]. 100 $\mu$ l of this suspension was administered to mice by gavage needle, before the infection with the pathogenic bacteria, or with cells killed by heating in water bath at $100{ }^{\circ} \mathrm{C}$ for $30 \mathrm{~min}$ [7]. Salmonella typhimurium was grown in liquid brain heart infusion (BHI) medium (Difco) for $18 \mathrm{hr}$ at $37^{\circ} \mathrm{C}$.

\section{Bacterial infection}

Mice were infected by the oro-gastric route with $0.1 \mathrm{ml}$ of the bacterial suspension containing about $2.5 \times 10^{7} \mathrm{cfu}$ which was obtained by using Mc Farland method [7]

\section{Experimental Design:}

Twelve albino male mice were randomly divided into four groups designated as 1, 2, 3, and 4. Each group consists of 3 mice, and subjected to the following treatments: Group1 was used as a negative control.Group2 was dosed with $0.1 \mathrm{ml}$ of $2.5 \times 10^{7} \mathrm{cfu} / \mathrm{ml}$ of Salmonella typhimurium culture and use as positive control. Group3 was fed with $0.1 \mathrm{ml}$ of $10^{9} \mathrm{cfu} / \mathrm{ml}$ viable Lactobacillus acidophilus culture, and infected with $0.1 \mathrm{ml}$ of $2.5 \times 10^{7} \mathrm{cfu} / \mathrm{ml}$ culture of Salmonella typhimurium. Group4 was fed with $0.1 \mathrm{ml}$ of $10^{9} \mathrm{cfu} / \mathrm{ml}$ heat killed Lactobacillus acidophilus culture for 7 days, and dosed with $0.1 \mathrm{ml}$ of $2.5 \times 10^{7} \mathrm{cfu} / \mathrm{ml}$ culture of Salmonella typhimurium. Mice were fed with a single dose $0.1 \mathrm{ml}$ of $10{ }^{9} \mathrm{cfu} / \mathrm{ml}$ Lactobacillus culture daily by oral administration for 7 consecutive days. At the $8^{\text {th }}$ day of experimental period, each mouse was infected with $0.1 \mathrm{ml} S$. typhimurium $\left(2.5 \times 10^{7}\right)$ by oral administration. After 6th day infection with Salmonella, mice were sacrificed by cervical dislocation and the blood samples of each mouse were collected to evaluate immunological parameters [8]. Other groups were sacrificed after 6 days from the experiment had begun.

\section{E. Total Leucocyte Count}

Blood samples were collected by heart puncture using a disposable insulin syringe $(1 \mathrm{ml})$ precoated with heparin. The method of WBC count [9] was followed in which an aliquot of $0.02 \mathrm{ml}$ blood was mixed with 0.38 $\mathrm{ml}$ of leucocyte diluents in a test tube and left at room temperature for 5 minutes. A drop of the mixture was applied to the surface of Neubauer chamber under the cover slip, and the chamber was left for 3 minutes to settle the cells. The leucocytes were counted in 4 large squares (each with 16 small squares) and the total count of leucocytes was obtained using the following equation:

Total Count $($ cell/cu.mm.blood $)=$ $\left(\frac{\text { Number of Cells Counted }}{4}\right) \times 20 \times 10$

\section{F. Absolute Count of Leucocytes}

One drop of blood was smeared on a clean slide using another slide and left to dry at room temperature. The smear was stained with Leishman stain for 5 minutes and buffered for 10 minutes, and then washed with tap water. The slide was air-dried, and then examined under oil immersion lens (100X) [9]' At least 100 leucocytes were examined, and the percentage of each type was recorded, while the total count of each type was obtained using the following equation:

Total Count $($ cell/cu.mm.blood $)=$ $\left(\frac{\text { Percentage of Cells x Total Count }}{100}\right)$

\section{G. Phagoctic Index}

Mice were anaesthetized with chloroform, and injected intraperitoneially with $3 \mathrm{ml}$ of normal.

Warm saline $\left(37^{\circ} \mathrm{C}\right)$, then the abdominal region was massaged for 3 minutes. After that mice dissected, and the peritoneal cells were collected with a pasture pipette and transferred to a clean test tube. The tube was centrifuged (2000 rpm/minutes) for 5 minutes and cells were suspended in $1 \mathrm{ml}$ of normal saline, counted and their number was adjusted to $10^{6}$ cell $/ \mathrm{ml}$. Also, the cell viability was assessed using trypan blue stain. To carry out phagocytosis, $0.2 \mathrm{ml}$ of $10^{3} \mathrm{cfu} / \mathrm{ml}$ cell suspension, $0.1 \mathrm{ml}$ of heat-killed backer yeast 
suspension and $0.1 \mathrm{ml}$ of human plasma $\mathrm{AB}$ were mixed in a test tube and incubated in a shaking water bath $\left(37^{\circ} \mathrm{C}\right)$. After 30 minute incubations, smears were made and the slides were air-dried, and fixed with methanol then stained with already prepared Giemsa stain for 15 minutes. The slides were examined under oil immersion lens (100X), and at least 200 yeast-phagocytic and non-phagocytic cells were randomly counted. The phagocytic activity was expressed as a phagocytic index, which was calculated using the following equation [10]:

$$
\begin{gathered}
\text { Phagocytic Index }(\%)= \\
\left(\frac{\text { Number of Phagocy tic Cells }}{\text { TotalCount }}\right) \times 100
\end{gathered}
$$

\section{H. Statistical analysis}

The values of the investigated parameters were given in terms of mean \pm standard error, and differences between means were assessed by analysis of variance (ANOVA) and Duncan test, using the computer programme SPSS version 7.5 [11] using a level of a significant

$\mathrm{p} \leq 0.05$.

\section{Results}

To investigate the immune effect of viable and heat killed $L b$. acidophilus against Salmonella typhimurium, mice were treated with viable and heat killed lactic acid bacteria and infected with Salmonella typhimurium. Mice treated with viable Lb.acidophilus showed a significant increase in total count (8367 \pm 669 cells/cu.mm blood) compared with negative control $(7450 \pm 366$ cells/ cu.mm blood) and positive control (3350 \pm 320 cells/cu.mm blood). A significant decrease in total count was observed in mice treated with heat killed Lb.acidophilus (3975 \pm 415 , $3625 \pm 201$ cells/cu.mm blood) compared with negative control. A significant variation in absolute count of leukocyte was observed between control groups and different groups of mice treated with viable and heat killed Lb.acidophillus as shown in Table (1)
Table (1)

Total and absolute count of leukocyte in mice treated with viable and heat killed

Lactobacillus acidoppilus and infected with

\begin{tabular}{|c|c|c|c|c|}
\hline Groups & $\begin{array}{c}\text { G1 } \\
\text { negative } \\
\text { control }\end{array}$ & $\begin{array}{c}\mathrm{G} 2 \\
\text { positive } \\
\text { control }\end{array}$ & $\begin{array}{c}\text { G3 } \\
\text { (Lb.acido } \\
\text { phillus } \\
\text { viable) }\end{array}$ & $\begin{array}{c}\mathrm{G} 4 \\
\text { (Lb.acido } \\
\text { phillus, } \\
\text { heat } \\
\text { killed } \\
\end{array}$ \\
\hline $\begin{array}{c}\text { Total } \\
\text { leukocye } \\
\text { count }\end{array}$ & $\begin{array}{c}7450 \pm 366 \\
a\end{array}$ & $\begin{array}{c}3350 \pm 320 \\
\text { b }\end{array}$ & $\begin{array}{c}8367 \pm 669 \\
\text { a b c }\end{array}$ & $\begin{array}{c}3975 \pm 415 \\
\text { a b c }\end{array}$ \\
\hline $\begin{array}{l}\text { Lymphoc } \\
\text { yte count }\end{array}$ & $\begin{array}{c}4990 \pm 385 \\
\mathrm{~A} \\
\end{array}$ & $\begin{array}{c}2220 \pm 52 \\
b\end{array}$ & $\begin{array}{c}5314 \pm 194 \\
\text { a b c } \\
\end{array}$ & $\begin{array}{c}2911 \pm 104 \\
\text { a c } \\
\end{array}$ \\
\hline $\begin{array}{l}\text { Neutroph } \\
\text { ile count }\end{array}$ & $\begin{array}{c}1996 \pm 83 \\
a \\
\end{array}$ & $\begin{array}{c}698 \pm 85 \\
\text { b } \\
\end{array}$ & $\begin{array}{c}2922 \pm 89 \\
\text { a b c } \\
\end{array}$ & $\begin{array}{c}980 \pm 120 \\
\text { a b c } \\
\end{array}$ \\
\hline $\begin{array}{c}\text { Monocye } \\
\text { count }\end{array}$ & $\begin{array}{c}849 \pm 124 \\
a\end{array}$ & $\begin{array}{c}225 \pm 24 \\
\text { b }\end{array}$ & $\begin{array}{c}899 \pm 49 \\
\text { a b c }\end{array}$ & $\begin{array}{c}310 \pm 77 \\
\text { a b c }\end{array}$ \\
\hline $\begin{array}{l}\text { Eosinoph } \\
\text { ile count }\end{array}$ & $\begin{array}{c}67 \pm 42 \\
\mathrm{a} \\
\end{array}$ & $\begin{array}{c}30 \pm 23 \\
\text { b }\end{array}$ & $\begin{array}{c}169 \pm 43 \\
\text { a b c } \\
\end{array}$ & $\begin{array}{c}39 \pm 25 \\
\text { a b c } \\
\end{array}$ \\
\hline $\begin{array}{c}\text { Basophil } \\
\text { e count }\end{array}$ & $\begin{array}{c}63 \pm 33 \\
\mathrm{a} \\
\end{array}$ & $\begin{array}{c}20 \pm 12 \\
b\end{array}$ & $\begin{array}{c}81 \pm 29 \\
\text { a c } \\
\end{array}$ & $\begin{array}{c}19 \pm 12 \\
\text { a c } \\
\end{array}$ \\
\hline
\end{tabular}

S. typhimurium and control groups.

*Values are expressed as mean $\pm \mathrm{SE}$.

*Within each raw values with different letters are significantly different $(\mathrm{p} \leq 0.05)$.

A significant variation in phagocytic index was observed between control groups and different groups of mice treated with viable Lb.acidophillus and heat killed Lb.acidophillus as showen in Table (2).

Table (2)

Phagocytic index of peritoneal cells in mice treated with viable and heat killed

Lactobacilli acidophilus and infected with $S$. typhimurium and control groub.

\begin{tabular}{||c||c||c||}
\hline Groups & $\begin{array}{c}\text { Phagocytic } \\
\text { index \% }\end{array}$ & $\begin{array}{c}\text { Statistical } \\
\text { Evaluation }\end{array}$ \\
\hline \hline G1 negative control & $\begin{array}{c}49.51 \pm \\
1.26\end{array}$ & $\mathrm{~A}$ \\
\hline \hline G2 positive control & $\begin{array}{c}45.6 \pm \\
1.3\end{array}$ & $\mathrm{~B}$ \\
\hline \hline $\begin{array}{c}\text { G3(L.acidophillus, } \\
\text { viable) }\end{array}$ & $\begin{array}{c}55.50 \pm \\
3.50\end{array}$ & $\mathrm{a} \mathrm{b}$ \\
\hline \hline $\begin{array}{c}\text { G4 (L.acidophillus } \\
\text { heat killed) }\end{array}$ & $\begin{array}{c}40.50 \pm \\
3.50\end{array}$ & $\mathrm{a} \mathrm{b}$ \\
\hline
\end{tabular}

*Values are expressed as mean \pm SE.

*Within each raw values with different letters are significantly different $(p \leq 0.05)$. 


\section{Discussion}

Results showed that feeding mice with viable Lb.acidophilus exhibited a significant increase in total and absolute count of leukocyte as compared with positive and negative control. This might be due to the ability of Lactobacillus species to display antagonistic effect against other bacteria such as E. coli and Salmonella typhimurium [12]. They were able to prevent an increase of pathogenic bacteria by production of antimicrobials such as organic acids, hydrogen peroxide and bacteriocins [13].

These results agreed with Perdigon et al. [14] who found that feeding milk fermented with a mixture of Lactobacillus casei and Lactobacillus acidophilus exhibited a protective effect against Salmonella typhimurium infection in mice. The same observation stated by Delneste et al. [15] who noted that mice fed with LAB exhibited a significant increased in IFN- $\gamma$ levels and this may reflect a selective influence of LAB on Th1 cell activation, higher lymphocyte proliferation responses and IFN- $\gamma$ production.

Results revealed that mice fed with viable Lb.acidophilus showed a significant increase in phagocytic index compared with negative and positive control groups. This result agreed with Gill et.al. [16] who found that feeding mice with $L b$. Rhamnosus, Lb. acidposophilus or $B$. lactis resulted in enhanced phagocyte function, and this caused a significant increase (66-100 \%) in the phagocytic activity of (monocytes and polymorphonuclear cells) compared with the control. Heat killed $L b$. acidposophilus showed a significant decrease in total and absolute count of leukocyte and phagocytic index compared with positive and negative controls. These results agreed with Kelly et.al [17] who found that neither $L b$ reuteri bacterial lysates, or killed bacteria had the ability to inhibit IL-8 synthesis which is induced by S.typhimurium T84 cells and play important role in Salmonella pathogenesis. A different study showed that the ability of heatkilled Mix-LAB to prevent bacterial infection in mice was found to be more significant than that of viable monostrain . Effect may be due to the activation of the immune system rather than to the adherence of LAB to the intestine epithelium [8].

\section{References}

[1] Marteau, P. R.; De Vrese, M.; Cellier, C. J. and Schrezenmeir, J. (2001). Protection from gastrointestinal diseases with the use of probiotics. Am. J. Clin. Nutr., 73(2): 430-436

[2] Doron, S. and Gorbach, S. L. (2006). Probiotics: their role in the treatment and prevention of disease. Expert Rev. Anti Infect Ther., 4(2):261-275.

[3]Sullivan, A. and Nord, C. E. (2005). Probiotics and gastrointestinal diseases. J. Intern. Med., 257(1): 78-92.

[4] Goossens, D.; Jonkers, D.; Stobberingh, E.; and Stockbrügger, R. (2003). Probiotics in gastroenterology: indications and future perspectives. Scand J. Gastroenterol Suppl., 239:15-23.

[5] Mercenier, A.; Pavan, S. and Pot, B. (2003). Probiotic as biotheraputic agent's present Knowledge and future prospects. Current pharmaceutical Design., 8: 99-101.

[6] Elmer, G. W.; Surawicz, C. M. and Mc Farland, L. V. (1996). Biotherapeutic agents. A neglected modality for the treatment and prevention of selected intestinal and vaginal infections. JAMA. 275: 870876.

[7] Lilian, M., Elizabeth, N.; Leda, Q. and Jacques, R. (2001). Protection by lactobacillus acidophilus UFV-H2B20 against experimental oral infection with Salmonella enterica subsp. Enterica Ser. Typhimurium gnotobiotic and conventional mice. Braz. J. Microbiol., 32(1)

[8] Lin WH, Yu B, Lin CK, Hwang WZ, Tsen HY, (2007). Immune effect of heat-killed multistrain of Lactobacillus acidophilus against Salmonella typhimurium invasion to mice. Appl Microbiol.; 102(1):22-31.

[9] Haen, P. J. (1995). Principles of Hematology. Edited by L. H. Young and W. B. Publisher, London. pp: 310-325.

[10] Metcalf, J. A.; Gallin, M. D.; Nauseef, M. D. and Root, R. K.(1986). Laboratory Manual of Neutrophil Function. Raven Press New York, U.S.A.

[11] McCullough, B.D. and Wilson, B (2005). "On the accuracy of statistical procedures in Microsoft Excel 2003." Computational Statistics and Data Analysis. Vol. 49, 12441252. 
[12] Coconnier, M.-H., Liévin, V., Lorrot, M. and Servin, A.L. (2000). Antagonistic activity of Lactobacillus acidophilus against intracellular Salmonella typhimurium infecting human enterocytelike Caco-2/ TC-7 cells. Appl. Environm. Microbiol. 66, 1152-1157.

[13] Oyetayo, V. O. (2004). Phenotypic characterization and assessment of the inhibitory potential of Lactobacillus isolates from different sources. Afri. J. Biotech. 3 (7): 355-3.

[14] Perdigon, G.; Alvarez, S., Pesce de Ruiz Holgado, A.A., (1990). Prevention of gastrointestinal infection using immunobiological methods with milk fermented with Lactobacillus casei and Lactobacillus acidophilus. J. Dairy Res. 57, 255-264.

[15] Delneste Y., Donnet-Hughes A., and Schiffrin E.J. (1998). Mechanisms of Action on Immunocompetent Cells. Nutr. Rev., 56, S93-S98.

[16] Gill, K.; J. Rutherfurd; J. Prasad and P. K. (2000). Enhancement of natural and acquired immunity by Lactobacillus rhamnosus (HN001), Lactobacillus acidophilus (HN017) and Bifidobacte riumlactis (HN019).British Journal of Nutrition, 83, 167-176.

[17] Kelly, D., J. I. Campbell, T. P. and S. Conway (2004). Commensal anaerobic gut bacteria attenuate inflammation by regulating nuclear-cytoplasmic shuttling of PPAR- $\gamma$ and ReIA. Nat. Immunol. 5:104112.

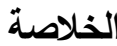

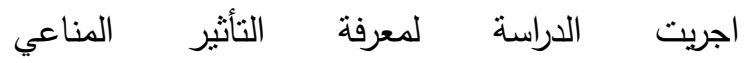

لبكتريا Lactobacillus acidophilus المقتولة بالحرارة

Salmonella بلى الفئران المصابة بيكتريا السالمونيلا typhimurium بكتريا Lb acidophilus الحية والمقتولة بالحرارة من خلال دراسة التعداد الكلي والتفريقي لكريات الدم البيضاء وعملية

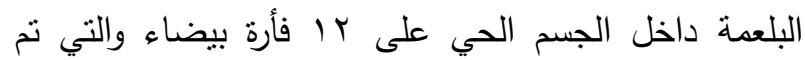
تقسيمها عشوائيا الى اربعة مجاميع ا و r وب و وـ وقد تضمنت كل مجموعة على ثلاثة فئران متساوية بالاعمار
والاحجام. عدت المجموعة (1) التي تم تغذيتها على العليقة

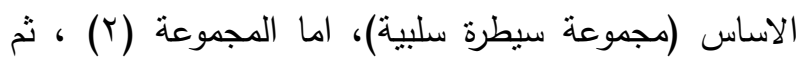
اصابتها بـ 0.1 مل من بكتريا S.typhimurium بعدد ، $\quad(2.5 \times 10 \quad 7 \mathrm{cfu} / \mathrm{ml}) \quad$ خلايا

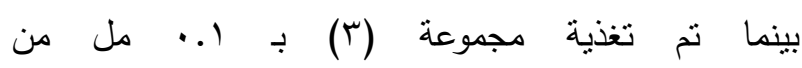

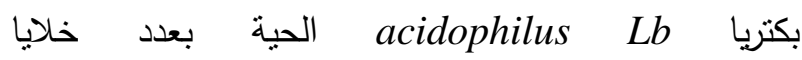
بكتربا 0.1 مل من $\left.0.1 \times 10^{9} \mathrm{cfu} / \mathrm{ml}\right)$ اما S.typhimurium

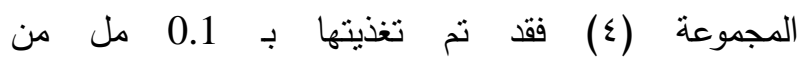
بكتريا بكتربا 0.1 cfu/ml $)$ S.typhimurium اظهرت النتائج ما يأتي: التأثير المعزز المناعي في الفئران التي جرعت ببكتريا Lb acidophilus الحية كان فعالا مقارنة مع مجموعة السيطرة بينما اظهرت الفئران المعاملة بيكتريا Lb acidophilus المقتولة بالحرارة انخفاضا معنويا في التعداد الكلي والتفريقي لكريات الدم البيضاء وعملية البلعمة بالمقارنة مع مجاميع السيطرة. 